\title{
CREATIVE CHARACTER EDUCATION IN THE UTILIZATION OF USED GOODS INTO VERTICULTURE IN CLASS IV SD N 7 KUTOSARI KEBUMEN
}

\section{Tri Saptuti Susiani, Noviatun Khasanah}

Universitas Sebelas Maret

noviatunkhasanah88@gmail.com

\section{Article History}

accepted 30/09/2018

approved $12 / 10 / 2018$

published 30/10/2018

Keywords

Kreatif, waste, vertikultur

\begin{abstract}
Humans use goods and services to meet the needs every day increasing. One alternative in overcoming this is to recycle used goods. Through creative character education for students class four of SD N 7 Kutosari by utilizing used items to become verticultur. The method used in this study is the stage of action research. The results of this study showed a significant increase in the first cycle shorting trash be based on his species and the second cycle showed the high creativity of students in the use of used plastic bottles as verticultur.
\end{abstract}

Social, Humanities, and Education Studies (SHEs): Conference Series https://jurnal.uns.ac.id/shes

p-ISSN 2620-9284 e-ISSN 2620-9292 


\section{PENDAHULUAN}

Manusia menggunakan barang dan jasa untuk memenuhi kebutuhan setiap hari semakin meningkat. Meningkatnya jumlah barang yang digunakan oleh manusia menyebabkan meningkatnya pula jumlah sampah yang dihasilkan setiap harinya. Perkembangan teknologi, perkembangan industri serta bertambahnya populasi penduduk merupakan faktor meningkatnya jumlah sampah khususnya sampah plastik. Peningkatan penggunaan plastik ini di indonesia mencapai kenaikan rata-rata 200 ton tiap tahunnya.

Menurut kementrian lingkungan hidup, pada tahun 2018 sampah yang dihasilkan mencapai 66,8 juta ton atau setiap orang dalam sehari mencapai $0,7 \mathrm{~kg}$ sampah. Plastik dan barang yang dapat dikelola oleh pemerintah hanya sebanyak $15 \%$ atau 10,02 juta ton. Hal ini menunjukkan bahwa sebanyak 56,78 juta ton sampah tidak dapat dikelola dan masuk ke dalam tempat pembuangan akhir (TPA). Sampah adalah barang yang dianggap sudah tidak terpakai dan dibuang oleh pemilik/pemakai sebelumnya, tetapi bagi sebagian orang masih bisa dipakai jika dikelola dengan prosedur yang benar (Nugroho, 2013 : 23). Permasalahan sampah merupakan hal yang krusial (sulit terselesaikan). Bahkan, dapat diartikan sebagai masalah kultural/kebiasaan karena dampaknya mengenai berbagai sisi kehidupan, terutama di kota besar.

Semakin meningkatnya sampah mengakibatkan meningkatnya masalah serius jika tidak disegera mencari jalan keluarnya. Pemerintah sudah merencanakan beberapa program dalam mengurangi jumlah sampah. Menurut nugroho ( $2013: 52$ ) langkah mengurangi sampah yaitu $5 \mathrm{M}$ yang terdiri dari mengurangi (reduce), menggunakan kembali (reuse), mendaur ulang (recycle), mengganti (replace) dan menghargai (respect). Mengurangi (reduce) adalah mengurangi penggunaan barangbarang habis pakai yang dapat menimbulkan sampah. Menggunakan kembali (reuse) adalah menggunakan kembali barang-barang yang masih dapat dipakai untuk memaksimalkan umur barang tersebut. mendaur ulang (recycle) adalah mengubah barang yang sudah tidak terpakai untuk menjadikan barang baru yang lebih bermanfaat. Mengganti (replace) adalah mengganti barang yang bersifat sekali pakai dengan barang yang lebih tahan lama dan menggunakan barang yang ramah lingkungan. Menghargai (respect) adalah meningkatkan rasa cinta kita kepada alam sehingga menimbulkan sikap bijak dalam sebelum memilih. Alternatif lain yang saat ini berkembang yaitu mengubah sampah plastik khusunya botol plastik, plastik bekas detergen, plastik bekas minyak goreng dan pipa paralon menjadi vertikultur.

Vertikultur tidak hanya sekedar kebun vertical, namun sesuatu yang dapat merangsang seseorang untuk menciptakan ide bidang pertanian di pekarangan yang sempit. Struktur vertikal, memudahkan pengguna membuat dan memeliharanya. Vertikultur tidak hanya memberikan sebagai sumber pertanian tetapi menciptakan keindahan alami yang mneyenangkan. Menurut mulatsih (dalam sari, 2017 : 89) vertikultur diambil dari istilah verticulture dalam bahasa inggris (vertical dan culture) artinya sistem budidaya pertanian yang dilakukan secara vertical atau bertingkat, baik didalam ruangan maupun diluar ruangan. Sistem pertanian vertikultur sangat cocok digunakan di daerah perkotaan dan lahan sempit. Kelebihan lainnya dari vertikultur adalah hemat air, hemat puput, meningkatkan produksi, sanitasi lingkungan, pertanian organik dan menyiasati iklim.

Mengubah sampah plastik menjadi vertikultur merupakan sikap kreatif karena mengubah barang tak terpakai menjadi barang yang lebih bermanfaat. Kreatif merupakan nilai pendidikan karakter yang telah dicanangkan oleh pemerintah dalam kurikulum 2013. Pendidikan merupakan suatu cara manusia dalam memanusiakan manusia dan merupakan hal yang wajib diperoleh oleh semua warga negara indonesia untuk menjadi manusia yang berakhlak mulia sesuai dengan tujuan pendidikan nasional yang dimuat dalam sistem pendidikan nasional dalam undang-undang nomor 
20 tahun 2003. Dalam sitem pendidikan nasional (sisdiknas) terdapat 18 nilai-nilai karakter, salah satunya yaitu nilai karakter kreatif. kreatif menurut munandar (2012 : 20) adalah kemapuan seseorang dalam menciptakan sesuatu yang baru. Kreativitas dikelompokkan menjadi 4P yaitu kreativitas pribadi, kreativitas proses, kreativitas produk, dan kreativitas press. Pada penelitian ini, peneliti berfokus pada peningkatan kreativitas produk. Kreativitas produk adalah kreativitas seseorang dalam mengkombinasi suatu hal yang telah ada menjadi sesuatu yang baru. Berdasarkan pemaparan diatas, dapat disimpulkan bahwa kreatif atau kreativitas adalah kemampuan sesorang dari dalam diri maupun dari luar diri untuk megkombinasi suatu hal yang telah ada menjadi sesuatu yang baru.

\section{METODE}

Metode yang digunakan pada penelitian ini adalah dengan menggunakan penelitian action research. Menurut Shani dan Pasmore (1985), action research adalah proses penelitian di mana pengetahuan tentang perilaku diientegrasikan dengan pengetahuan tentang organisasi dann keduanya diimplementasikan untuk menyelesaikan permasalahan nyata organisasi. Tujuan action research adalah menyelesaikan permasalahan praktis sembari mengembangkan ilmu pengetahuan. Penelitian dilaksanakan di SD N 7 Kutosari Kebumen. Subjek penelitian ini adalah kelas IV tahun ajaran 2018/2019 berjumlah 28 siswa yang terdiri dari 15 laki-laki dan 13 perempuan. Teknik pengumpulan data dengan pengamatan (observation), kuisioner (questionnaire) dan wawancara (interview). Penelitian ini dilaksanakan selama dua siklus yang terdiri atas dua pertemuan. Setiap pertemuan terdiri atas perencanaan, pelaksanaan, observasi dan refleksi.

\section{HASIL DAN PEMBAHASAN}

Siklus pertama dilakukan dengan tahap perencanaan, pelaksanaan, observasi dan refleksi. Pada tahap perencanaan dilakukan kegiatan, seperti pemberian wawasan pengelolaan sampah berbasis konsep 5M. Awalnya, siswa kelas IV membuang berbagai macam sampah hanya pada satu tempat sampah. Dengan demikian, kegiatan perencanaan ini mulai menarik perhatian siswa kelas IV SD $\mathrm{N} 7$ Kutosari Kebumen dibuktikan dengan siswa kelas IV memilah sampah yang mereka hasilkan. Mereka mengelompokkan sampah menjadi sampah organik, sampah plastik, sampah kaca dan kaleng dan sampah kertas. Sampah organik yaitu sampah yang dapat terurai dalam tanah yang terdiri dari sampah dedaunan, makanan sisa dan ranting pohon. Sampah plastik yaitu sampah yang tidak dapat terurai dalam tanah seperti sampah botol plastik, gelas plastik, dan bungkus makanan plastik. Sampah kaca dan kaleng adalah sampah yang dikhususkan untuk sampah kaleng dan kaca. Sedangkan sampah kertas yaitu sampah yang khusus untuk sampah kertas, kardus, dan koran.

Pemilahan sampah pada tahap observasi terlihat sampah sudah tidak ditempatkan pada satu tempat sampah. Sampah telah dikelompokkan dalam 4 tempat sampah yang berbeda sesuai dengan jenis sampah yang dihasilkan siswa. Siswa mulai memanfaatkan barang bekas seperti gelas plastik untuk kreasi kincir angin dan kertas untuk hiasan dinding. Lingkungan sekolah SD N 7 Kutosari Kebumen tidak ada sampah yang berserakan, sampah dikelompokkan sesuai jenisnya. Pada tahap refleksi, terdapat beberapa saran dan masukan sebagai perbaikan, khususnya dalam hal pemanfaatan barang bekas untuk vertikultur. 


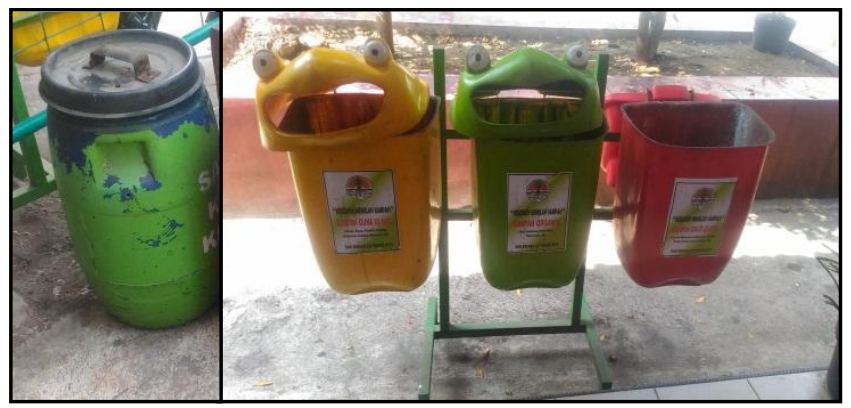

Gambar 1. Siswa Mengelompokkan Sampah

Siklus kedua dilaksanakan dengan tahapan yang sama yakni perencanaan, pelaksanaan, observasi dan refleksi. Namun dengan menambahkan beberapa saran dan masukan dari hasil refleksi pada siklus pertama. Pada tahap perencanaan dilakukan kegiatan, antara lain: pemberian wawasan kreatif dalam penggunaan barang bekas dan sistem tanam vertikultur. Siswa kelas IV awalnya tidak mengetahui kreasi barang bekas dari botol plastik. Mereka cenderung lebih mengetahui kreasi dari gelas plastik menjadi berbagai bentuk seperti kincir angin dan tempat tanam tanaman dari gelas plastik. Bentuk tempat tanam dari gelas plastik yaitu gelas plastik dilubangi bagian bawah gelas menggunakan paku dan bagian atas diikat dengan kawat. Dengan demikian, kegiatan perencaan ini mulai menarik perhatian siswa kelas IV SD N 7 Kutosari Kebumen dibuktikan dengan adanya pengumpulan botol plastik dari sampah siswa.

Siswa diperbolehkan mengembangkan kreativitasnya dalam membentuk tempat tanam vertikultur. Sebanyak 12 siswa memotong botol bekas pada bagian samping memanjang, bagian samping lainnya dilubangi dengan paku yang telah disiapkan oleh guru dan bagian atas dan bawah diikat dengan kawat untuk membentuk rangkaian sistem vertikultur. Sebanyak 10 siswa memotong botol plastik menjadi dua bagian, kemudian bagian bawah tiap bagian ditusuk menggunakan paku yang telah disiapkan oleh guru dan bagian atas diikat dengan kawat untuk membentuk rangkaian sistem vertikultur. Sebanyak 6 siswa memotong botol plastik 3/4 bagian dari bawah. Siswa tersebut membuat berbagai karakter hewan seperti panda, kelinci dan beruang di bagian atas dan menghias bagian luar botol dengan cat sesuai karakter hewan yang dibuatnya supaya lebih menarik. Siswa yang lain juga menghias vertikultur yang mereka bentuk supaya lebih menarik. Setiap anak mencoba kegiatan tersebut dengan antusias. Siswa juga menanam tanaman yang telah disiapkan oleh guru. Tanaman tersebut berupa tanaman strawberry, tanaman cabai dan beberapa tanaman hias.

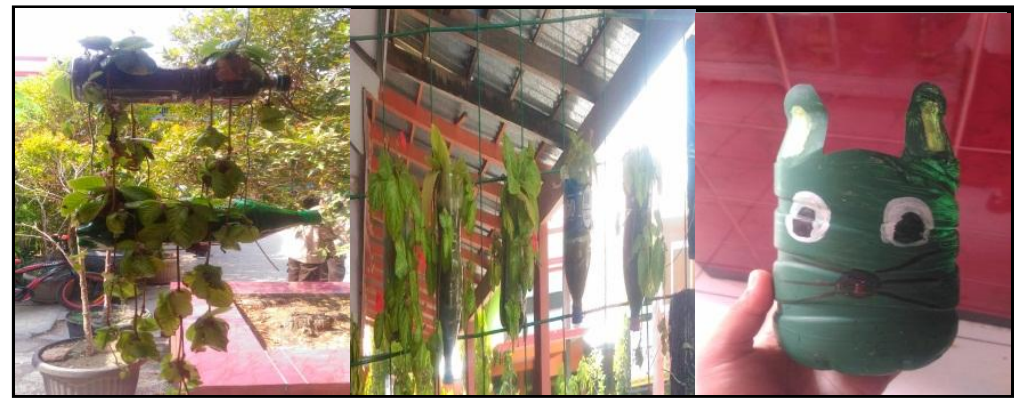

Gambar 2. Bentuk Vertikultur Siswa 


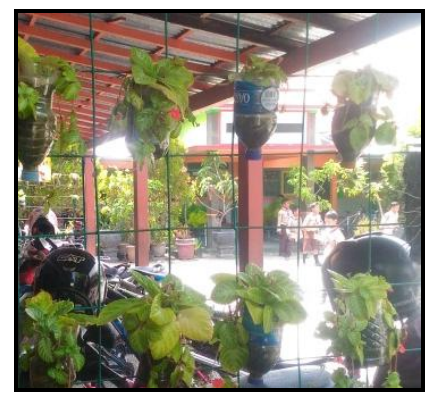

Gambar 3. Tanaman Siswa Pada Vertikultur

Penanaman tanaman pada botol plastik bekas pada tahap observasi terlihat tanaman yang ditanam pada botol plastik bekas dengan sistem vertikultur dapat tumbuh dengan baik. Menurut Sitawati (2011 : 125-130), tanaman strawberry yang ditanam dengan sistem vertikultur memberikan keuntungan dan percepatan berbuah dari pada teknik tanam sistem hortikultur. Keunggulan sistem tanam vertikultur menurut Gribald (2015), sistem tanam vertikultur memiliki keunggulan pertumbuhan yang sangat signifikan dengan menggunakan lahan yang sempit namun dengan perolehan hasil yang tinggi. Hal ini menunjukkan bahwa sistem vertikultur memiliki manfaat khususnya pengelolaan pertanian pada lahan sempit untuk menghasilkan hasil yang tinggi.

Pemanfaatan barang bekas untuk membuat sistem vertikultur diharapkan dapat mengurangi jumlah sampah plastik, lingkungan tertata rapi dan terawat, dan mengembangkan kreativitas siswa kelas IV di SD N 7 Kutosari Kebumen tahun ajaran 2018/2019.

\section{SIMPULAN}

Penggunaan barang untuk memenuhi kebutuan setiap hari semakin meningkat. Sampah yang dihasilkan juga semakin meningkat. Sampah kususnya sampah plastik tidak dapat terurai di tanah dan dapat memberikan dampak negatif seperti membawa bibit penyakit. Sampah harus dikelola dengan baik supaya tidak memberikan dampak negatif bagi manusia. Oleh karena itu, perlu adanya alternatif dalam mengurangi barang bekas khususnya barang plastik. Salah satu alternatif tersebut yaitu dengan memanfaatkan botol bekas untuk tempat tanam vertikultur. Pemanfaatan ini dapat meningkatkan pendidikan karakter kreatif pada siswa kelas IV SD $\mathrm{N} 7$ Kutosari Kebumen Tahun Ajaran 2018/2019.

\section{DAFTAR PUSTAKA}

Gribald, Nurlaili. (2015). Mixed Modification Planting Media to The Growth of Celery Plants (Apium gravolens L.) on Verticulture System. Vol. 10, No. 1

Munandar. (2012). Pengembangan Kreativitas Anak Berbakat. Jakarta: Gramedia Pustaka Utama.

Nugroho panji. (2013). Panduan membuat kompos cair. Jakarta : pustaka baru press.

Sari. (2017). Metode Konversi Sampah Plastik Berupa Botol Plastik Bekas Melalui Budidaya Toga Dengan Sistem Vertikultur Yang Ramah Lingkungan. Gontor Agrotech Science Journal Vol. 3 No. 2.

Shani dan Pasmore. (1985). Organization inquiry : toward a new model of the action research process. Contemporary organization development: current thinking and applications.

Sitawati. (2011). Optimization of Plant Growth and Yield Through Innovation of The Materials and Medium Verticulture. Jakarta : Pustaka Baru Press.

Undang-undang nomor 20 tahun 2003. 